\title{
6 Operating Hours, Working Times and Employment in the Netherlands
}

Lei Delsen and Jeroen Smits

\subsection{Introduction}

In this chapter, we report the results of the 2003 Dutch EUCOWE survey on operating hours and working times in the Netherlands. The collected data are representative for all branches of the Dutch economy. In our descriptive analysis two questions are central: to what extent do operating hours differ from agreed individual daily and weekly working time, and how is the decoupling of working time and operating time achieved?

In the Netherlands, both from the policy point of view and from the scientific point of view, there is a clear need for new data and analyses of operating times, working times and their relationship. Structural changes in the business environment - steeper international competition, increased customer orientation, and order driven production systems - render flexibility and duration of operating hours more and more important. An optimal use of the capital goods is increasingly necessary to compete. However, despite its clear importance, research on operating time in the Netherlands is underdeveloped. The major reason for this is lack of data. The only national study in which some information is gathered on operating hours in the various sectors of economic activity in the Netherlands is the bi-annual Labour Demand Panel of the Institute of Labour Studies (Organisatie voor Strategisch Arbeidsmarktonderzoek, OSA). Information on the relationship between operating hours and working time in the Netherlands is very scarce and tends to be limited to some data presented in the OSA-reports (Bekker et al., 2003) and some branch information (e.g. De Lange, 1989; Gradus, 1996; Tijdens, 1998). With the EUCOWE survey this data gap is closed to an important extent.

The Dutch EUCOWE sample consists of 1,886 establishments. Valid information on operating hours is available for 1,836 establishments, which together represent 446,073 employees. The data contain case weights that make it possible to study operating hours and working time patterns both from an establishment/organisational perspective and from an employee perspective. Unless otherwise stated, in the remainder of this chapter when we speak of-characteristics of-establishments, establishment proportional weighting 
is applied and when we speak about - characteristics of - employees, employee proportional weighting is used.

The structure of this chapter is as follows. In Section 6.2, the results are presented for the different measures of operating hours. First, an overview is presented of the length of the daily and weekly operating hours and of the weekly operating days in the producing and service sectors. Second, three measures of weekly operating hours are addressed. Third, the developments (1998-2003) of operating hours and employment are explored, according to branch and establishment size. Fourth, the links between operating hours and establishment characteristics are examined. Section 6.3 presents information on the use of working time frames. The differences between economic sectors and size classes in the use of part time work, shift work, staggered working times, Saturday and Sunday work, overtime, temporary work and on-call labour are addressed. The relationships between operating time and the working time patterns are established. In Section 6.4, the associations between the use of the various working time options within Dutch establishments are analysed to gain an insight into the existence of certain "working time strategies". Section 6.5 investigates the relationship between fluctuations in demand or activity of establishments and the measures taken by the establishments to cope with these fluctuations. Section 6.6 draws the main conclusions.

\subsection{Operating hours}

\subsubsection{Daily and weekly operating hours}

In this section, both daily and weekly operating hours are discussed, and two different measures of operating hours are used. The direct measure concerns the answers directly given by the respondents to the question about the number of hours per day and per week, and the number of days per week the establishment was in operation. ${ }^{1}$ The indirect measure concerns the mean weekly operating hours and is constructed on the basis of the number of employees and the duration of the various working time patterns. Hence, this measure not only looks at the duration, but also at the labour intensity of operating time.

1 The following three questions were asked in the EUCOWE survey: "What is the operating time of your establishment on a usual working day?", "How many hours did your establishment operate in the usual week in March or April?", and "In the usual week in March or April, did your establishment operate on ......?" 
Depending on the application, the direct measure can be proportionally weighted according to the number of establishments or employees. If we discuss the operating hour regimes of Dutch establishments, we use the establishment proportional weighted measure. However, because there are many more smaller than larger establishments, this measure does not give a good indication of the operating hour regimes experienced by Dutch employees. To gain an insight into the latter, establishments have to be weighted by their number of employees and employee proportional weighting is more appropriate. Because the number of employees working in the various patterns is central to the construction of the indirect measure, establishment proportional weighting makes no sense with this measure and only the employee proportional weighted version is presented.

At the macro level, operating hours very much depend on the openness of the economy, its industry structure, and the size of plants in a country. Also the business cycle situation is of importance. In Table 6.1 , the directly measured daily and weekly operating times, and the weekly operating days for the Netherlands in 2003 are presented. More than half (52\%) of all establishments have a daily operating time of 8 hours or less. Around $81 \%$ of the establishments operate no more than 10 hours daily. This concerns twothirds of the employees. Almost $70 \%$ of the establishments are daily 8 to 10 hours in operation, covering almost $60 \%$ of the Dutch employees. So the majority of establishments and organisations in the Netherlands have a "standard" of 8-10 daily operating hours. The mean daily operating time is 9.4 hours. This matches well with the legal maximum daily working times mentioned in the Working Hours Act. ${ }^{2}$ A large minority (19\%) of the establishments has a nonstandard daily operating time of more than 10 hours; this concerns $34 \%$ of employees. Only a small minority of $2.1 \%$ of the establishments is in operation for 24 hours a day. From the fact that these establishments represent around $15 \%$ of the employees it may be concluded that these are mainly very large establishments.

There are differences between the producing and service sectors, as well as between size classes. Table 6.1 shows that average daily operating hours are somewhat shorter in the producing sector relative to the service sector. Establishments with a daily operating time of 8 hours or less are more frequent

2 The Working Hours Act of 1996 determines the maximum and minimum regarding the working day, working week, daily rest, weekly rest, overtime, etc. Under this act, the maximum working time per day has been increased by half an hour to 9 hours. Sector or company agreements can be up to a maximum of 10 working hours per day. Including incidental overtime, up to 12 working hours per day are allowed. 
Table 6.1. Establishments and employees in daily and weekly operating hours, and weekly operating days' categories in 2003 (in \%; using the direct measure)

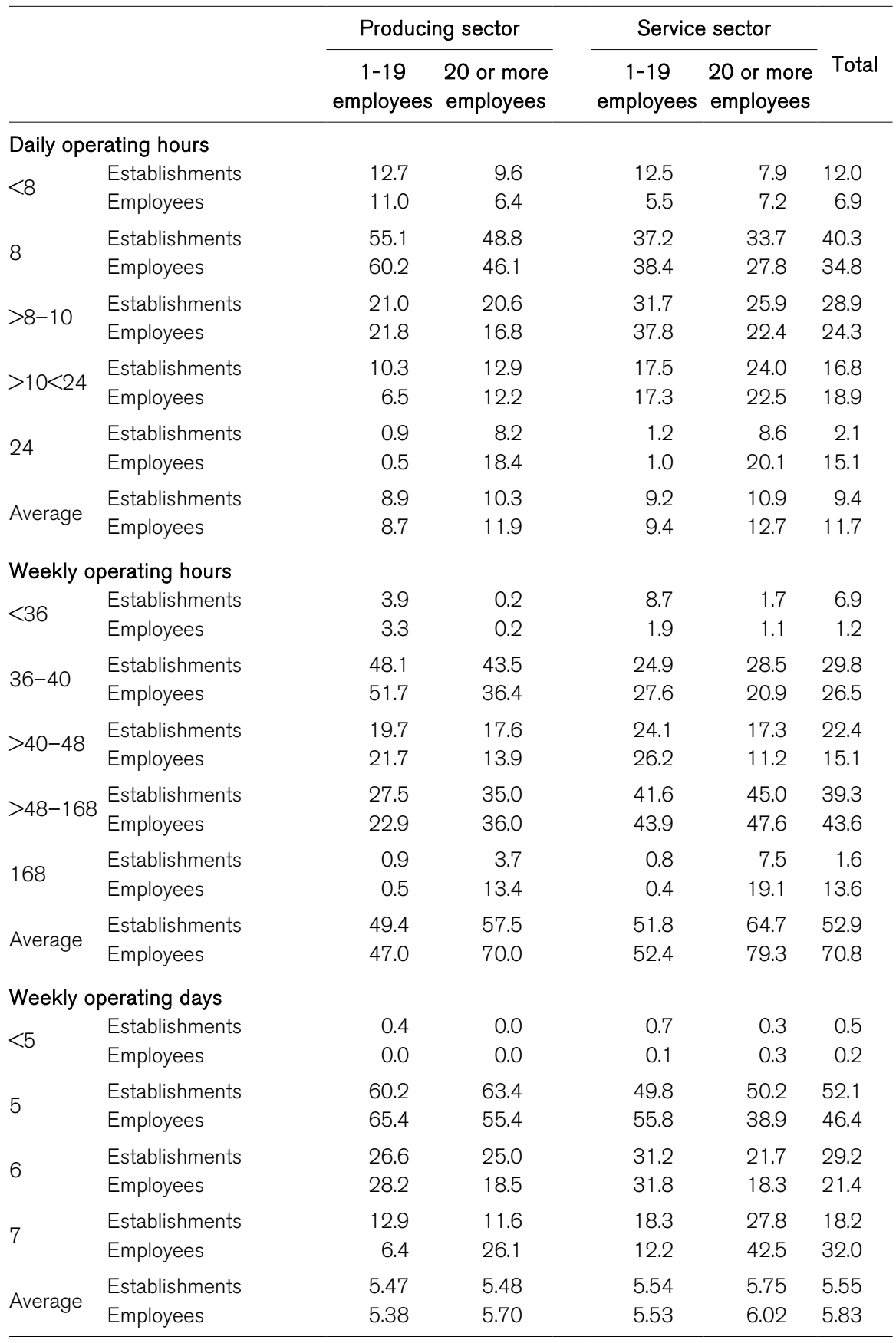


in the producing sector and establishments with more than 8 and less than 24 hours less frequent. These differences are emphasised when the results are weighted by the number of employees. The proportion of establishments with a daily operating time of 24 hours and the proportion of employees working in such establishments do not differ much across sectors. As expected, in both sectors small $(<20$ employees) establishments tend to have shorter daily operating hours than establishments with 20 or more employees.

Table 6.1 also shows that around $37 \%$ of the establishments have weekly operating times of 40 hours or less; concerning $28 \%$ of the employees. This indicates that a considerable part of the Dutch establishments operate 5 days per week or less. The data on weekly operating days show that this applies to over half of the establishments (52.1\%), covering $46.4 \%$ of the employees. Only a few establishments $(0.2 \%)$ operate less than 5 days per week. The mean number of weekly operating hours is 52.9, and the mean number of operating days is 5.6. The proportion of establishments that operate 40-48 hours is $22.4 \%$, covering $15.1 \%$ of the employees. This is consistent with the finding that $29.2 \%$ of the establishments operate six days a week; representing $21.4 \%$ of the employees. The category of establishments operating more than 48 hours and less than 168 hours is most frequent (39.3\%), involving $43.6 \%$ of the employees. Only a minority of the establishments $(1.6 \%)$ is open 24 hours a day and 7 days a week, but it concerns $13.6 \%$ of the employees. So, more than half of all Dutch employees work in establishments operating more than 48 hours per week. There are rather a high proportion of establishments $(18.2 \%)$ that work 7 days per week and almost onethird of the employees work in such establishments. This result, combined with the finding that a large majority of Dutch establishments operate 8-10 hours a day, suggests that the decoupling of operating time and individual full time working hours in the Netherlands is mainly realised by operating more days per week. As we will see below in Section 6.3, also part time contracts are a major source of decoupling in the Netherlands.

Like daily operating hours, weekly operating hours and weekly operating days are longer in the service sector relative to the producing sector, and in both sectors weekly operating hours and weekly operating days increase with establishment size (see Table 6.1). The similarities between daily and weekly operating hours are expected, for weekly operating time is the product of number of daily operating hours and number of weekly operating days. In the producing sector the $36-40$ hours category is most important. Over $60 \%$ of the establishments in this sector operate 5 days per week and around $50 \%$ operate 8 hours per day. The over 48 hours category comes second in the producing sector, and a quarter of the establishments operate 6 days a week. In the service sector the over 48 hours category is the most important, representing 
over $40 \%$ of the establishments as well as of the employees. In the service sector the 36-40 hours category comes second. As in the producing sector, 5 operating days per week is also most frequent in the service sector. However, of the large establishments almost $28 \%$ operate 7 days a week, which is more than twice as frequent as in the producing sector. In the large service sector establishments operating hours of 168 are also more frequent than in the large producing sector establishments, and also cover a higher proportion of employees. For instance, processing industry, intramural health care and computer centres operate continuously.

It may be concluded that decoupling - the divergence between working hours and operating hours - is stronger and more frequent in the service sector and in larger establishments. More extensive decoupling makes increasing demands on the logistic and organisational procedures of the establishments. For instance, more rosters and time tables are needed, part time jobs are introduced or extended, and employees are expected to work on irregular days and times (e.g. Saturdays and/or Sundays or shifts). Section 6.4 deals with the relationship between operating hours and working time frames in more detail.

\subsubsection{Three measures of weekly operating hours}

In Table 6.2 three measures of weekly operating times are presented. Based on the direct measure, the establishment proportional weighted mean weekly operating hours in the Netherlands in 2003 was 52.9 hours. This result is consistent with the figure from the Institute of Labour Studies (OSA), which found the directly measured weekly operating hours to be 57 hours for establishments with 5 or more employees in 2001, the latest year for which figures are available (Bekker et al., 2003). The somewhat higher value of the OSA may be due to the fact that the smallest establishments, which according to Table 6.2 have the shortest operating times, are absent from its data. The employee proportionally weighted operating hours, 70.8 hours, are substantially higher than the establishment proportionally weighted hours. This reflects the fact that most employees are working in the larger establishments with longer operating hours. The indirectly (employee weighted) operating time is with 51.2 hours substantially shorter.

There are clear differences in weekly operating hours between sectors of the Dutch economy. These differences vary with the measure applied (see Table 6.2). In the construction sector the absolute, 9 hours difference between the direct and the indirect measures is relatively small, whereas, in social services, the difference of more than 30 hours is relatively large. Personal services record the longest establishment proportional weekly operating hours and both employee weighted measures are also high. The employee propor- 
Table 6.2. Weekly operating hours of establishments and employees (directly and indirectly measured) by sector and establishment size in the Netherlands in 2003

\begin{tabular}{|c|c|c|c|c|c|}
\hline \multirow[b]{2}{*}{ Sector } & \multirow[b]{2}{*}{ Measurement } & \multicolumn{3}{|c|}{ Size class } & \multirow[b]{2}{*}{ Tota } \\
\hline & & $\begin{array}{c}1-19 \\
\text { employees }\end{array}$ & $\begin{array}{c}20-249 \\
\text { employees }\end{array}$ & $\begin{array}{c}250+ \\
\text { employees }\end{array}$ & \\
\hline \multirow{3}{*}{ Primary sector } & Direct establ & 56.2 & 49.2 & $(84.4)$ & 56.0 \\
\hline & Direct empl & 48.9 & 49.4 & (93.6) & 52.1 \\
\hline & Indirect empl & 36.5 & 37.2 & (33.5) & 36.5 \\
\hline \multirow[t]{3}{*}{ Secondary sector } & Direct establ & 46.6 & 63.4 & 88.2 & 51.4 \\
\hline & Direct empl & 47.7 & 68.5 & 92.6 & 74.6 \\
\hline & Indirect empl & 36.1 & 55.0 & 66.7 & 56.8 \\
\hline \multirow[t]{3}{*}{ Construction } & Direct establ & 46.0 & 46.5 & $(45.2)$ & 46.1 \\
\hline & Direct empl & 45.4 & 46.2 & $(52.2)$ & 46.6 \\
\hline & Indirect empl & 38.0 & 37.1 & $(39.8)$ & 37.6 \\
\hline \multirow{3}{*}{ Distributive services } & Direct establ & 52.4 & 62.3 & 90.0 & 53.6 \\
\hline & Direct empl & 54.2 & 63.6 & 86.7 & 63.1 \\
\hline & Indirect empl & 35.3 & 50.6 & 70.1 & 47.4 \\
\hline \multirow[t]{3}{*}{ Producer services } & Direct establ & 43.4 & 50.7 & 71.6 & 44.4 \\
\hline & Direct empl & 45.8 & 52.3 & 75.2 & 56.9 \\
\hline & Indirect empl & 35.6 & 42.2 & 59.0 & 45.0 \\
\hline \multirow[t]{3}{*}{ Social services } & Direct establ & 47.7 & 65.4 & 107.7 & 53.9 \\
\hline & Direct empl & 49.2 & 76.4 & 111.0 & 90.0 \\
\hline & Indirect empl & 33.3 & 49.8 & 71.7 & 58.2 \\
\hline \multirow[t]{3}{*}{ Personal services } & Direct establ & 62.0 & 86.0 & $(96.9)$ & 63.5 \\
\hline & Direct empl & 77.1 & 87.5 & (87.3) & 84.8 \\
\hline & Indirect empl & 46.0 & 67.4 & $(53.4)$ & 60.3 \\
\hline \multirow[t]{3}{*}{ Total } & Direct establ & 51.3 & 61.2 & 92.5 & 52.9 \\
\hline & Direct empl & 51.4 & 65.4 & 95.9 & 70.8 \\
\hline & Indirect empl & 36.0 & 49.3 & 66.9 & 51.2 \\
\hline
\end{tabular}

Figures between brackets are based on too few establishments to be reliable.

tional direct measure of operating time is highest in the social services (90 hours) and shortest in construction (46.6 hours). Based on the establishment proportional direct measure the shortest weekly operating hours are in producer services (44.4) and based on the employee proportional indirect measure, in the primary sector (36.5). Table 6.2 also clearly shows that for all three measures, weekly operating time increases with establishment size: for small establishments it is below average and for medium-sized and large establishments it is above average. The only exceptions are the direct measure for the primary sector and the indirect measure for construction. The largest establish- 
ments $(250+)$ in the social services have the longest weekly operating hours (both direct measures $>100$ ) of all Dutch establishments.

\subsection{3 (Changes in) operating hours and employment}

The EUCOWE data allow the role that operating hours play in job creation in the Netherlands to be studies. The available information at the level of individual establishments allows an analysis of the relationship between (changes in) operating hours and (changes in) employment. Certain aspects of the working time models set out in Chapter 1 suggest that longer operating time relative to competitors ceteris paribus reduces unit costs because of more effective use of equipment, buildings, machinery and vehicles and hence increases competitiveness, resulting in higher sales requiring expansion of production. From this we expected to find a positive relationship between the (development of the) duration of operating time and the (development of the) number of employees employed. On the other hand, the productivity and unit costs of labour may increase with operating hours. Thus, the relationship between employment and operating hours is an empirical one. The EUCOWE data indeed seem to confirm for the Netherlands the existence of a positive relationship between the two variables, but the effects are not very strong. The Pearson correlation between the direct measure of weekly operating hours and the number of employees of establishments in 2003 has a value of 0.10 and the Pearson correlation between the changes in weekly operating hours and in number of employees in the period 1998-2003 has a value of only 0.03.

To look at the changes in operating hours and employment in more detail, Table 6.3 presents their percentage change in the period 1998-2003 split according to economic sector and establishment size. We see that between 1998 and 2003 average weekly operating hours in the Netherlands increased by $0.7 \%$ and the number of employees increased on average by $2.8 \%$. The strongest increase in average weekly operating hours $(2.21 \%)$ was in personnel services, the smallest increase in weekly operating time was in construction $(0.22 \%)$. The strongest increase in employment $(7.33 \%)$ was in producer services. The strongest drop in employment was recorded in the distributive services $(-1.61 \%)$, while operating hours in this sector increased by $0.72 \%$.

These developments are influenced by the business cycle, the increase in employment intensity of economic growth and the changes in the regulations of operating time and working time. Between 1998 and 2000 the Dutch economy reached its peak; a recession followed. In 2003 the Netherlands experienced negative economic growth. A considerable proportion of the jobs created in the boom were part time and flexible jobs (see Delsen, 2002). As a result, the employment intensity of economic growth increased. Under the 
Table 6.3. Development of directly measured employee proportional weekly operating hours and employment 1998-2003 (in \%)

\begin{tabular}{llcccc}
\hline \multirow{2}{*}{ Sector } & & \multicolumn{3}{c}{ Size class } & \\
\cline { 3 - 5 } & Measurement & $\begin{array}{c}1-19 \\
\text { employees }\end{array}$ & $\begin{array}{c}20-249 \\
\text { employees }\end{array}$ & $\begin{array}{c}\text { 250+ } \\
\text { employees }\end{array}$ & Total \\
\hline Primary sector & Operating hours & 1.94 & -0.55 & $(0.00)$ & 0.93 \\
& Employment & 2.68 & 4.18 & $(26.64)$ & 4.30 \\
Secondary sector & Operating hours & -1.41 & 0.99 & 0.73 & 0.66 \\
& Employment & -2.31 & -1.43 & -0.86 & -1.33 \\
Construction & Operating hours & 0.56 & 0.13 & 0.00 & 0.22 \\
& Employment & -3.57 & 3.56 & -7.36 & 2.00 \\
Distributive services & Operating hours & 0.49 & 0.99 & 0.44 & 0.72 \\
& Employment & -3.93 & -0.86 & 2.66 & -1.61 \\
Producer services & Operating hours & 1.23 & 0.16 & 0.53 & 0.52 \\
& Employment & 3.57 & 6.90 & 11.37 & 7.33 \\
Social services & Operating hours & 1.61 & 1.02 & 0.14 & 0.51 \\
& Employment & 7.68 & 4.09 & 8.57 & 6.51 \\
Personal services & Operating hours & 10.58 & 0.59 & $(0.00)$ & 2.21 \\
& Employment & -2.30 & 3.12 & $(16.01)$ & 3.31 \\
& Operating hours & 1.17 & 0.78 & 0.33 & 0.66 \\
Total & Employment & -0.63 & 2.22 & 6.48 & 2.78 \\
\hline
\end{tabular}

Figures between brackets are based on too few establishments to be reliable.

1996 Working Hours Act, the maximum working hours per week has been decreased by 3 hours to 45 hours, although with incidental overtime, 48 hours per week are allowed. The development in the distributive services mentioned above may be related to legal changes in 1996 in the shop opening hours. ${ }^{3}$ Also, in the secondary sector, employment fell on average (-1.33\%), despite the growth in operating hours of $0.66 \%$. An explanation for this relative decrease of employment may be the increase in labour productivity (see Schettkat and Reijnders, 1998).

The growth rate of weekly operating hours decreases with establishment size (except in the secondary sector), while employment growth increases very strongly with establishment size. Between 1998 and 2003 small establishments

3 On June $1^{\text {st }}$, 1996 the Shop Closing Act of 1976 was replaced by the Shop Opening Act, by which the opening hours of Dutch shops were liberalised. The new act allows shops to be open between 06.00 and 22.00 from Monday to Saturday and also on twelve Sundays a year. 
recorded the strongest increase $(1.17 \%)$ in weekly operating hours, while at the same time - unlike the larger firms and organisations - they experienced an absolute fall $(-0.6 \%)$ in the number of employees. The strongest extension of operating hours (over 10\%) was in small establishments in personal services and the sharpest drop $(-1.41 \%)$ in small secondary sector establishments. The strongest employment growth (over 11\%) was in the large establishments in the producer services. The sharpest drop in employment between 1998 and $2003(-3.93 \%)$ was in small distributive services establishments. In the secondary sector, operating hours decreased in small establishments and increased in medium and large sized establishments, and employment fell in all size classes, being the strongest in the small establishments. For distributive services the growth rate of weekly operating hours by size class is an inverted U-shape, while for the producers' services it is U-shaped. It may be concluded that in the Netherlands there is neither a straightforward relationship between operating hours and employment, nor between the business cycle and operating time and employment.

\subsubsection{Operating hours and establishments characteristics}

Sector and size class are not the only characteristics of establishments that are related to operating hours. Such a relationship can also be expected with regard to other characteristics, such as capital intensity and the composition of the work force.

Capital intensity is an important establishment characteristic that is of influence on operating hours and on working time management. For highly capital-intensive establishments, the extension of operating hours may lead to a more efficient use of capital. Hence we expect operating hours to be longer in capital intensive establishments relative to labour intensive establishments. In the EUCOWE survey, capital intensity is measured by asking about the percentage of labour costs in total costs of the establishment. Table 6.4 shows that this percentage is on average $42 \%$ in Dutch establishments, and that it is somewhat higher in larger establishments and in the service sector. The expected negative relationship with operating hours is confirmed for the Netherlands. All correlations between labour costs and operating hours have the expected negative sign. Moreover, the relationship is much stronger in the producing sector than in the service sector, where it is only present in the smaller establishments. This is consistent with the production and services models of working time outlined in Chapter 1.

Besides labour costs, also the proportion of skilled personnel may influence operating hours. In part, the same reasoning applies as in the case of capital intensity: in establishments where highly trained employees are the most 


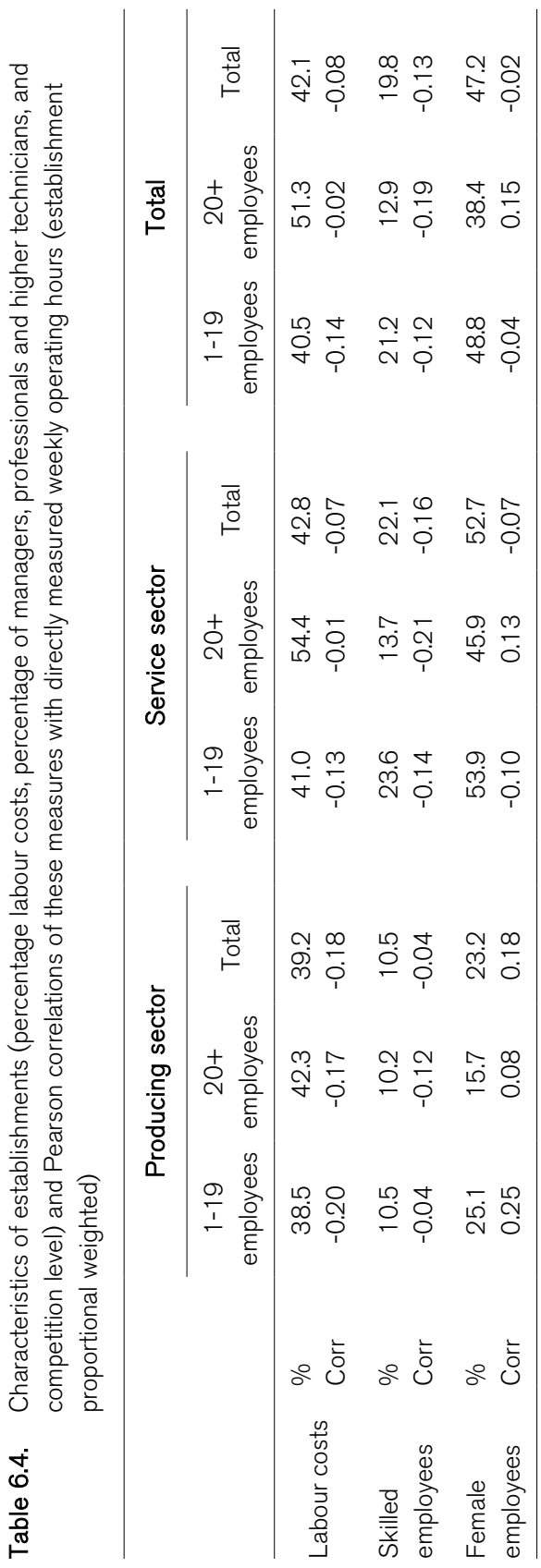


important capital - like in many services - extension of operating hours and working times might lead to a more efficient use of that human capital. However, in contrast with capital goods, the maximum working time of employees is legally restricted and hence the possibility to let them work longer is restricted. Extension of operating hours will, therefore, generally make it necessary to hire additional personnel, which in establishments with many skilled employees is relatively expensive.

Table 6.4 shows that the proportion of skilled employees - in the EUCOWE survey this is measured by the percentage of managerial, professional and higher technical staff - is, on average, $20 \%$ in the Netherlands. There are substantial differences between the producing sector and the service sector. In the producing sector the proportion of skilled employees is about $10 \%$, both in small and in large establishments. In the service sector, in contrast, the average percentage of skilled employees is $22 \%$, more than twice as high. There is also a clear difference between smaller and larger establishments; small service sector establishments have the highest percentage of skilled employees - almost a quarter of their personnel belong to this group.

The correlation between the proportion of highly trained employees and operating hours is negative in all sector-size classes. This confirms the idea that extension of operating hours is relatively expensive in establishments with many skilled personnel and that the relationship with operating hours for human capital is opposite to the relationship for capital goods. As expected the negative correlations are stronger in the service sector and especially in the larger service-sector establishments.

Table 6.4 shows that on average $47 \%$ of the employees of Dutch establishments are female. The proportion of female employees in large establishments $(38 \%)$ is lower than in small establishments $(49 \%)$. There are also large differences among economic sectors. Many services rely predominantly on female employees. Table 6.4 shows that establishments in the producing sector have only $23 \%$ female employees, whereas in the service sector females constitute more than half (53\%) of the staff. In both sectors, the female rate decreases with employment size. The correlation between the operating hours and the female rate shows a mixed picture. However, in the larger establishments in both sectors this correlation is positive, suggesting that either large establishments may use female employees to extend their operating hours or that large establishments with long operating hours offer more employment possibilities for females (who in the Netherlands mostly work part-time). 


\subsection{Working time patterns}

\subsubsection{Average working time and decoupling}

The relationship between duration of operating time and employment is influenced by the working time patterns applied. Table 6.5 presents information on the use of a number of 'special' working time patterns that are regularly used by Dutch employers to run their business. Table 6.5 starts with an overview of the average contractual weekly working time of establishments. The mean of the average working time of Dutch establishments is 28.6 hours, and Dutch employees on average work 30.6 hours per week. The most important variation is with regard to sector, with longer working times in the producing sector than in the service sector. Average contractual weekly working time in the service sector is 5 to 6 hours shorter than in the producing sector. Differences in number of part time contracts account for this variation.

The information on average weekly working time of establishments in Table 6.5 can be combined with the information on directly calculated operating hours of establishments in Table 6.2 to get a simple indicator of the degree of decoupling of operating hours and working time. If we divide the latter by the former, we see that in the Netherlands in 2003 the average weekly operating hours of establishments were 52.9/28.6 $=1.85$ times as high as the average weekly contractual working hours of employees. This figure is a little higher than the value of 1.54 that emerges from the OSA data for 2001 (Bekker et al., 2003). Based on OSA data, earlier research concluded that in the second half of the 1990s in the Netherlands an increasing decoupling of operating and working times had taken place, measured by the ratio between operating hours and full time working hours (Delsen and Smits, 2002). Although the EUCOWE data differ in several respects from the OSA data, the finding of a decoupling rate of 1.85 for 2003 seems to suggest that the trend towards increasing decoupling may have continued in the first years of the $21^{\text {st }}$ century.

\subsubsection{Part time work}

The - by international standards - low weekly working time ( 28.6 hours) in the Netherlands can be explained by the very widespread use of part time work. In the Netherlands part time employment is a normal phenomenon in working life of employees and in working time models of enterprises. Table 6.5 shows that part time employment contracts - defined as working 1-34 hours per week - are used by $70 \%$ of Dutch establishments in 2003 . The part time contract rate among the employees working in the EUCOWE establishments is $37 \%$. This figure is quite similar to the $34.5 \%$ found in the Labour 


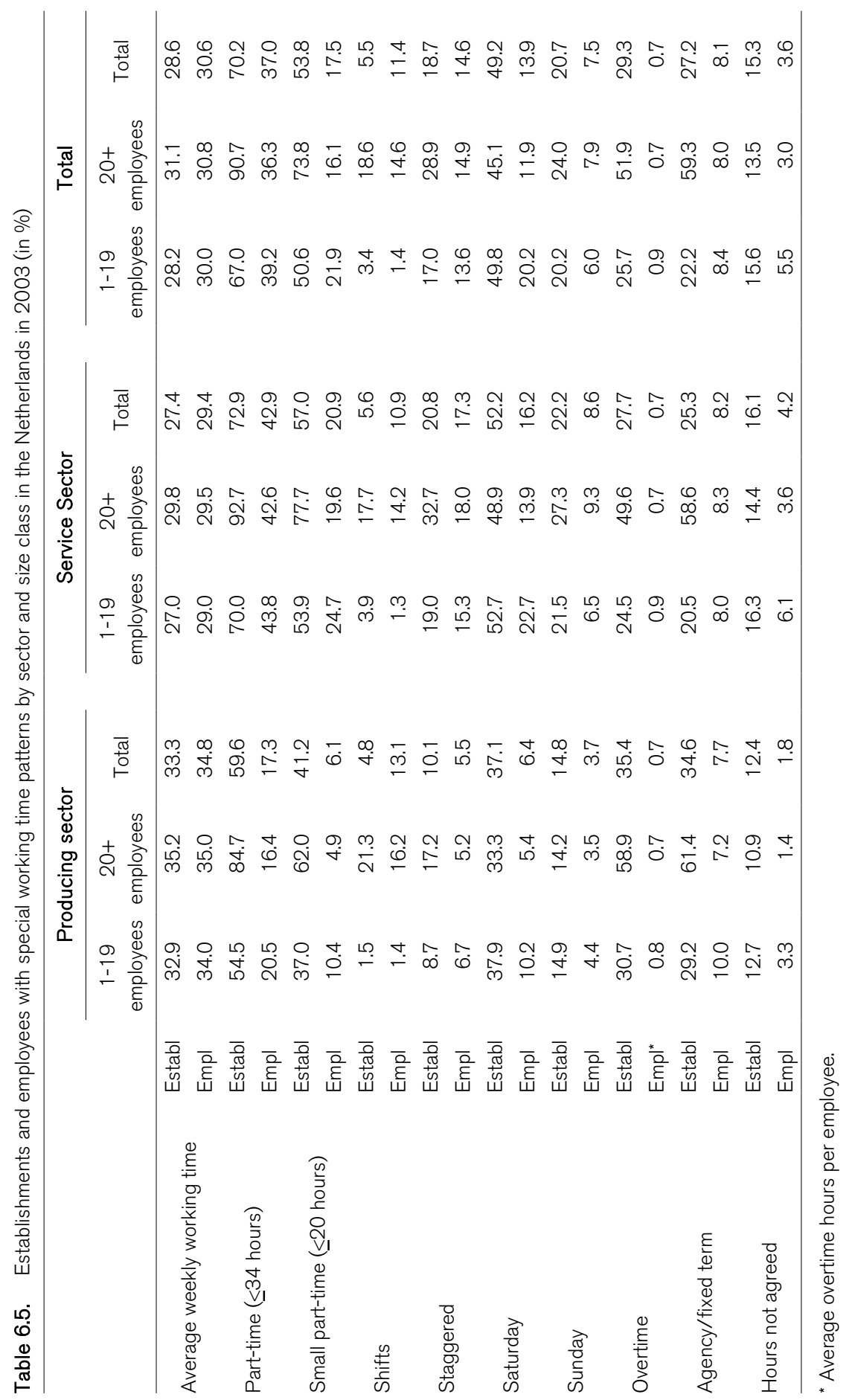


Force Survey for 2003, referring to persons who usually work less than 30 hours per week (OECD, 2004: 311). It is the highest rate in the European Union. In comparison with other EU-countries, in the Netherlands also short(er) part time contracts ( $\leq 20$ hours per week) are widely used. Over half of the establishments use them, involving $17.5 \%$ of all employees, or almost half of all part time workers. The proportion of establishments using part time work increases strongly with establishment size, but the proportion of the whole labour force working part-time is lower in large establishments. This may be due to the fact that larger establishments are more able to cope internally with uncertainties and selective personnel shortages and surpluses than smaller establishments (Delsen, 1995), but it may also be due to a different composition of their work force. The EUCOWE data show a strong positive correlation between the female rate and the part time rate $(0.52)$ and the short part time rate $(0.40)$. Table 6.5 shows that the percentage of part time employees in the service sector is $42.9 \%$ more than twice as high as in the producing sector (17.3\%) and the share of employees with short part time jobs in the service sector is more than three times as high as in the producing sector.

\subsubsection{Shift work}

The principle means of extending the daily operating hours are overtime work and shift work. Apart from the use of part time work, shift work and staggered working time strongly contribute to the decoupling of individual working time and capital operating time. Like overtime work, extra shifts are a typical adjustment to upward changes in demand or production. Table 6.5 shows that a minority of $5.5 \%$ of the establishments in the Netherlands use shifts, covering $11.4 \%$ of the employees. The incidence of shift work, as well as the proportion of employees working shifts is considerably higher in larger than in smaller establishments, notably in the producing sector. This does not come as a surprise. Shift schedules require a certain workforce size, i.e. a minimum number of employees are needed (see e.g. Burns and Carter, 1985). This may explain why shift work is more frequent in larger establishments (Anxo et al., 1995). Also other establishment characteristics play a role, including capital intensity. There are some differences between sectors. In the service sector relatively more establishments (5.6\%) use shifts than in the producing sector $(4.8 \%)$, while in the producing sector relatively more employees work shifts $(13.1 \%)$ than in the service sector $(10.9 \%)$. Among small ( $<20$ employees) service sector establishments, shift work is more widely used $(3.9 \%)$ than among small producing sector establishments (1.5\%), but the proportions of employees working shifts is about the same. For the larger establishments the picture is different. Among the $20+$ establishments in the producing sector not 
only the proportion of establishments using shifts (21.3\%), but also the proportion of employees affected (17.7\%) are higher than in the larger service sector establishments (with $16.2 \%$ and $14.2 \%$ respectively).

\subsubsection{Staggered working time}

Table 6.5 shows that $18.7 \%$ of the establishments in the Netherlands use staggered working times, covering $14.6 \%$ of the employees. The larger establishments $(28.9 \%)$ use staggered working times more often than the smaller ones $(17.0 \%)$. The proportion of employees working staggered working time, however, only differs slightly between small $(13.6 \%)$ and larger establishments (14.9\%). Although establishments use staggered working time far more often than shift work, the proportions of employees involved do not differ that much. This is related to the high proportion of shift work among very big establishments in the producing sector.

There are considerable differences between sectors. Service sector establishments use staggered working times (20.8\%) twice as often as establishments in the producing sector $(10.1 \%)$. The share of employees in staggered working times in the service sector $(17.3 \%)$ is three times as high as in the producing sector (5.5\%). In both sectors the proportion of establishments using staggered working times increases with establishment size. However, the proportion of employees working these kinds of shifts in the producing sector is lower in the larger establishments (5.2\%) than in the smaller establishments $(6.7 \%)$, while in the service sector the proportion is higher in the larger establishments $(18.0 \%)$ than in the smaller ones $(15.3 \%)$.

\subsubsection{Working on Saturday and Sunday}

Working Saturdays or Sundays is a principle means to extend the number of hours worked per week. Working on Saturdays is more widely used by establishments than working on Sundays. About half of the establishments (49.2\%) operate on Saturdays and a little less than $21 \%$ on Sundays (see Table 6.5). Hence, working on Saturday is a very common means to (permanently) extend operating time in the Netherlands. Service sector establishments use Saturday working (52.2\%) and Sunday working (22.2\%) much more often than establishments in the producing sector (37.1\% and $14.8 \%$ respectively). Weekend work and establishment size are linked. The number of establishments that operate on Saturdays decreases with establishment size in the producing sector as well as the service sector. The number of establishments that use Sunday working increases with establishment size in the service sector, and decreases slightly with establishment size in the producing sector. 
The proportion of employees working on Saturdays is 13.9\%; for working on Sundays it is $7.5 \%$. The legal restrictions on Sunday work and the extra compensation for working weekends, notably Sundays may play a role here. The percentages of service sector employees working on Saturday (16.2\%) or on Sunday $(8.6 \%)$ are more than twice as high as in the producing sector (6.4\% and 3.7\% respectively). The proportion of all employees working on Saturday decreases with establishment size, while the proportion of employees working on Sunday increases with establishment size. The latter difference is related to the positive relationship between establishment size and proportion of employees working on Sunday in the service sector.

\subsubsection{Overtime work}

Overtime is a very flexible and reversible way of extending operating hours. Overtime work can also be seen as an indicator of low adaptability of the other working time arrangements. Working overtime is restricted by legislation, but also by the need to pay premia. Table 6.5 shows that $29 \%$ of all Dutch establishments use overtime. Establishments in the producing sector (35.4\%) use overtime more often than service sector establishments $(27.7 \%)$. In both sectors the larger establishments use overtime much more often than the smaller establishments. The average number of overtime hours per employee is 0.7 . Given the average contractual weekly working time of Dutch employees of 30.6 hours, this means that overtime may lead to an extension of working time in the Netherlands of about $2 \%$. Differences in the average number of overtime hours between sectors of activity are small. The proportion of employees working overtime decreases with establishment size in both sectors. This may be due to the fact that larger establishments are more able to cope internally with uncertainties and selective personnel shortages and surpluses than smaller establishments. Also other establishment characteristics may play a role, including the proportion of female employees.

\subsubsection{Temporary and on-call labour}

To handle short-term variations in demand or activity, temporary employees (agency workers and employees on fixed-term contracts) can be hired. If the variations in demand are irregular on-call labour can be used as a solution. Table 6.5 shows that, on average, $27 \%$ of the establishments use temporary employees and $15 \%$ use on-call labour, concerning $8 \%$ and $4 \%$ of all employees respectively. The proportion of establishments using temporary employees increases strongly with establishment size, from $22 \%$ to $59 \%$. On-call labour, on the other hand, is used more often by smaller establishments. This is true 
both in the producing and in the service sector. However, temporary employees are used more often by establishments in the producing sector than in the service sector, whereas on-call workers are used more often by establishments in the service sector.

The percentage of employees working on temporary and on-call contracts decreases with the size of the establishment from $8.4 \%$ to $8.0 \%$ (1-19 and $20+$ ), and $5.5 \%$ to $3.0 \%$ respectively. This confirms earlier findings based on establishment data from a large scale European survey (Delsen, 1995). Small establishments rely more heavily on external mobility than larger establishments. In part this is related to the fact that employment protection regulations are more stringent for large firms. There are differences between sectors. In the producing sector the proportion of temporary employees decreases with the size of the establishments, while in the service sector it increases slightly with establishment size. The percentages of employees with on-call contracts in both sectors are clearly higher in the smaller establishments. This again may be due to the fact that larger establishments are more able to cope internally.

\subsubsection{Correlations: operating hours and working time patterns}

To gain insights into the relationship between operating hours and the working time patterns used in Dutch establishments, the Pearson correlations between the directly measured weekly operating hours and average working time and the various working time patterns are presented in the bottom line of Table 6.6. Working longer hours offers the opportunity to operate longer. We expected longer working time for employees to increase operating time. However, our data produce a negative relationship: longer operating hours are accompanied by shorter average weekly working time, suggesting a trade-off between operating time and working time. Interestingly, part-time is not correlated with operating hours. This finding is in line with the idea that the high level of part time work in the Netherlands is mainly the results of the preferences of employees and much less of strategic use of it as an instrument for extending operating hours. The strong growth of the number of part time jobs in the last decades in the Netherlands can be ascribed mainly to the demands of employees, which are acted upon by the employers. Dutch part time employees are known to be more satisfied with their jobs than full-timers, i.e. voluntary part time work prevails (Delsen, 1995; Buddelmeyer, Mourre and Ward, 2004). 
Table 6.6. Pearson correlations among working time patterns in Dutch establishments in 2003 (establishment-proportional weighted)

\begin{tabular}{lcccccccccc}
\hline & AWT & PT & SPT & Shifts & Stag & Sat & Sun & Overt & AFT & HNA \\
\hline $\begin{array}{l}\text { Average working } \\
\text { time }\end{array}$ & 1.00 & -0.84 & -0.90 & -0.03 & -0.09 & -0.18 & -0.14 & 0.08 & -0.14 & -0.26 \\
$\begin{array}{l}\text { \% Part time } \\
\text { employees }\end{array}$ & -0.84 & 1.00 & 0.73 & 0.02 & 0.08 & 0.11 & 0.08 & -0.14 & 0.11 & 0.19 \\
$\begin{array}{l}\text { \% Small part time em- } \\
\text { ployees }\end{array}$ & -0.90 & 0.73 & 1.00 & 0.02 & 0.09 & 0.17 & 0.14 & -0.10 & 0.12 & 0.18 \\
$\begin{array}{l}\text { \% Employees in shifts } \\
\text { \% Employees in stag- }\end{array}$ & -0.03 & 0.02 & 0.02 & 1.00 & -0.02 & 0.08 & 0.11 & 0.04 & 0.21 & 0.02 \\
$\begin{array}{l}\text { gered working time } \\
\text { \% Employees working }\end{array}$ & -0.09 & 0.08 & 0.09 & -0.02 & 1.00 & 0.05 & 0.08 & 0.04 & 0.06 & -0.04 \\
$\begin{array}{l}\text { on Saturday } \\
\text { \% Employees working }\end{array}$ & -0.18 & 0.11 & 0.17 & 0.08 & 0.05 & 1.00 & 0.44 & 0.08 & 0.02 & 0.19 \\
$\begin{array}{l}\text { on Sunday } \\
\begin{array}{l}\text { Average overtime } \\
\text { hours per employee }\end{array}\end{array}$ & 0.08 & -0.14 & -0.10 & 0.04 & 0.04 & 0.08 & 0.08 & 1.00 & 0.06 & 0.09 \\
$\begin{array}{l}\text { \% Employees in } \\
\text { agency/fixed term } \\
\text { work }\end{array}$ & -0.14 & 0.11 & 0.12 & 0.21 & 0.06 & 0.02 & 0.03 & 0.06 & 1.00 & 0.16 \\
$\begin{array}{l}\text { \% Employees with } \\
\text { hours not agreed }\end{array}$ & -0.26 & 0.19 & 0.18 & 0.02 & -0.04 & 0.19 & 0.23 & 0.09 & 0.16 & 1.00 \\
$\begin{array}{l}\text { Weekly operating } \\
\text { hours (directly mea- } \\
\text { sured) }\end{array}$ & -0.04 & 0.00 & 0.04 & 0.29 & 0.21 & 0.26 & 0.34 & 0.11 & 0.09 & -0.05 \\
\hline
\end{tabular}

The rather strong positive correlations between operating hours and the use of shifts, staggered working time and Saturday and Sunday working can be interpreted as resulting from the fact that these are all strategies used to lengthen operating hours. The fact that the correlations with overtime and temporary work are less strongly positive and that the correlation with the use of on-call labour is even negative is in agreement with the idea that these are mostly strategies for coping with fluctuations and not for extending operating hours permanently.

\subsection{Working time strategies?}

The various working time options and labour contracts mentioned in the previous section that are used to adapt operating hours (i.e. to decouple) may be related. A simple way to determine whether there are certain management strategies related to working time is to establish the Pearson correlations 
between the various working time and employment contract options (see Table 6.6).

With the exception of overtime work, all options presented have a negative relationship with the average contractual weekly working hours. The negative correlations between average contractual working time and the various working time patterns, including those used to extend operating hours, again point towards a trade-off between operating time and working time. The small but positive association of overtime with average contractual working time may be explained from the negative association between the proportion of overtime and the proportion of part-timers: part time work is a substitute for (expensive) overtime (Delsen, 1995). In the Netherlands paid overtime work is mainly concentrated among full time contracts (Delsen, 2002).

The strong negative relationship between average weekly working hours and (short) part time employment does not come as a surprise. A high proportion of part time contracts, notably of few hours, reduces the average contractual weekly working time. The correlation between short part time employment and average weekly working time is stronger $(-0.90)$ than all other correlations. Also labour on-call (hours not agreed) has - as expected - a considerable negative association with the average contractual working time.

The other negative associations with average weekly working time are less straightforward. Working during weekends, working on Saturdays (-0.18) more than working on Sundays $(-0.14)$ has the second strongest negative association. This may be explained in part from the positive association of weekend working with part time employment and short part time jobs and, in particular, with on-call labour (hours not agreed). Part-timers may be brought in at (predictable) peak times and to cover regular and anticipated variations in demand. They prevent underemployment of full time staff during off-peak periods and overtime payments in busy periods. The negative association between overtime work and part time employment confirms this. Part-timers may also enable establishments to remain open longer (e.g. at evenings or weekends). Hence, weekend working increases the demand for part time work. As a result the average weekly working hours will be lower (Delsen, 1995). So, the shift in operating time from 5 to 6 days per week does not necessarily imply an extension of working time for all full time employees. From this, at the establishment level, a positive correlation between the proportion of employees working weekends (Saturday and/or Sunday) and part time work can be expected, which is indeed present in our data. The negative relationship between average contractual working time and shift work can be explained from the fact that Dutch collective labour agreements require special working time reductions for shift workers. Together these relationships offer an expla- 
nation of the above mentioned trade-off between operating time and working time.

One may expect that capital intensive firms that use shift work or staggered work to extend operating hours will have less need to use part time work. Hence part time work may play the same role for small and medium sized firms as shift and staggered work does for the large firms. From this reasoning, a negative association between the proportions of part time work and shift or staggered work can be expected (Van Ginneken, 1988). However, in the case of the Netherlands this may be different because of the prevalence of voluntary part time work. Much of the part time work in the Netherlands therefore is not in the first place created to increase flexibility of establishments, but to fulfil the demands of employees. For this reason no strong associations between the extent of part time work and the presence of shift or staggered work that are used to lengthen operating hours can be expected. The correlations in Table 6.6 indeed indicate little association between the percentage of employees in shifts and proportion of employees working part-time. However, establishments staggered working times are used in combination with part time employment contracts.

The introduction of a reversible shift is an important means to flexibly expand operating hours. The temporary extension of operating time through an additional second or third shift may be realised by mainly appointing agency workers. ${ }^{4}$ The latter may explain the relatively strong positive correlation between the agency/fixed-term work rate and shift work.

The positive association between Saturday working and Sunday working is high and does not come as a surprise. Neither does the positive association between shift work and weekend working.

During the 1990s, Dutch industry used increasing amounts of overtime, especially on Saturdays. Due to shorter delivery times (just in time), industrial firms have to concentrate production on the desired moments implying that firms are confronted with more variation in busy and slack times, maintenance outside the production time and a more optimal use of the capital goods has become increasingly necessary (Tijdens, 1998:28). Hence, overtime work and Saturday working are positively associated. This is to some extent confirmed by the Dutch EUCOWE data, although the positive correlation coefficient

4 July 2004 Nedcar (3,800 permanent employees), the only Dutch automobile manufacturer owned by Mitsubishi, extended its shifts from two to three with an additional night shift and engaged 900 additional agency workers. Ten weeks later it was decided to end the night shift and reduce the number of shifts again to two. All agency workers will loose their job (Delsen, 2005). 
(0.08) is rather low. Also the positive association found between Sunday working and overtime can be explained in this manner.

Fixed-term contracts may be used when fluctuations are predictable, while overtime and agency work may be used when fluctuations are unpredictable. In the case of irregular variations in demand, on-call labour is also a solution. Temporary jobs (agency work and fixed-term contracts) and on-call labour may either be a substitute or a complement for part time employment. An interesting result from the management strategy perspective is the positive and relatively strong association between the proportion of employees without agreed number of working hours, the proportion of (short) part time jobs and the proportion of agency and fixed-term contract workers. These positive associations suggest that these forms of contracts are complements and confirm earlier research results by Delsen (1995: 209) for the Netherlands. Like part time work and agency work, on-call labour goes together with working on Saturdays and even more with working on Sundays, which suggests that this form of labour might be used for instance by shops, to fill in the extended opening hours. Hence, on the one hand, on-call labour plays the same role in working time management as part time employment, on the other hand, the positive association with overtime and temporary work and agency work confirms that on-call labour is used as part of an ad hoc employment flexibility strategy.

The decoupling of working and operating hours through the use of the various forms of working time arrangements - part time work, shift work, staggered working times, weekend work and overtime - aims to improve adaptability to fluctuations in capacity utilisation due to movements in production and demand. In general, shift work and part time work are used to meet extended demand, to make better use of capital equipment, to extend production capacity and to cope with predictable fluctuations in demand. Overtime, temporary work and agency work are more often used to deal with unpredictable fluctuations in demand and seasonal peaks.

Table 6.7 presents an overview of the different forms of fluctuations that Dutch establishments have to cope with. It shows that $25 \%$ of Dutch establishments experience substantial fluctuations in demand or activity. Establishments most frequently (23\%) experience yearly fluctuations, $18 \%$ experience weekly fluctuations and $16 \%$ daily fluctuations. The incidence of fluctuations is highest in the larger establishments, especially in the producing sector, where $35 \%$ of establishments have to cope with yearly fluctuations and a quarter of establishments with weekly fluctuations. 
Table 6.7. Establishments with considerable fluctuations according to kind of fluctuations (in \%)

\begin{tabular}{|c|c|c|c|c|c|}
\hline & \multicolumn{2}{|c|}{ Producing sector } & \multicolumn{2}{|c|}{ Service sector } & \multirow[b]{2}{*}{ Tota } \\
\hline & $\begin{array}{c}1-19 \\
\text { employees }\end{array}$ & $\begin{array}{l}20 \text { or more } \\
\text { employees }\end{array}$ & $\begin{array}{c}1-19 \\
\text { employees }\end{array}$ & $\begin{array}{l}20 \text { or more } \\
\text { employees }\end{array}$ & \\
\hline Daily fluctuations & 17.3 & 16.6 & 14.9 & 20.5 & 16.0 \\
\hline Weekly fluctuations & 19.8 & 25.6 & 16.6 & 22.1 & 18.0 \\
\hline Yearly fluctuations & 20.7 & 35.4 & 22.5 & 27.1 & 23.1 \\
\hline Only foreseeable & 8.2 & 13.2 & 6.2 & 10.5 & 7.3 \\
\hline Only unforeseeable & 6.5 & 8.7 & 9.9 & 6.0 & 8.9 \\
\hline $\begin{array}{l}\text { Both foreseeable and unforesee- } \\
\text { able }\end{array}$ & 10.9 & 16.9 & 7.8 & 13.6 & 9.3 \\
\hline $\begin{array}{l}\text { Total with considerable fluctua- } \\
\text { tions }\end{array}$ & 25.5 & 38.7 & 24.0 & 30.0 & 25.4 \\
\hline
\end{tabular}

To cope with these fluctuations several measures can be taken which can be divided into internal and external forms of flexibility (see e.g. Delsen, 2002). Internal quantitative forms of flexibility are overtime, short-time, flexible working times, shifts, staggered working time and changing holiday dates. The use of hiring and firing, the change of shift systems, temporary contracts and agency workers are external quantitative forms of flexibility.

Table 6.8 shows that overtime is the most widely spread measure used to cope with fluctuations; almost $70 \%$ of the establishments use it for this purpose. Overtime is used a little more by the larger establishments, but the difference with the smaller ones is not very large. There are also hardly any differences in its use between the sectors. The use of Saturday work and of external employees (agency workers, subcontracting, on-call labour and freelancers) comes second at around $40 \%$. Both strategies are most often used

Table 6.8. Measures taken to cope with fluctuations by sector and establishment size (in \%)

\begin{tabular}{lccccccr}
\hline & \multicolumn{2}{c}{ Producing sector } & & \multicolumn{2}{c}{ Service sector } & \\
\cline { 2 - 3 } & $\begin{array}{c}1-19 \\
\text { employees }\end{array}$ & $\begin{array}{l}\text { 20 or more } \\
\text { employees }\end{array}$ & & $\begin{array}{c}1-19 \\
\text { employees }\end{array}$ & $\begin{array}{c}\text { 20 or more } \\
\text { employees }\end{array}$ & \\
\hline Overtime & 69.5 & 76.0 & & 68.0 & 75.9 & \\
Short time work & 21.7 & 13.7 & & 25.3 & 17.8 & 23.7 \\
Saturday work & 58.7 & 39.7 & & 37.0 & 30.0 & 40.1 \\
Sunday work & 22.4 & 6.0 & & 20.0 & 12.2 & 18.7 \\
Change shift system & 3.2 & 14.2 & & 1.7 & 9.5 & 3.7 \\
Staggered working time & 14.6 & 7.5 & & 18.5 & 29.8 & 18.6 \\
Flexible working times & 9.0 & 9.0 & & 16.9 & 31.9 & 16.9 \\
External employees & 60.3 & 81.1 & & 29.7 & 52.7 & 40.8 \\
Hiring and firing & 24.9 & 32.2 & & 19.6 & 47.0 & 24.6 \\
Other & 12.2 & 6.8 & & 19.7 & 17.1 & 17.3 \\
\hline
\end{tabular}


in the producing sector, where Saturday work is a strategy used more by the smaller establishments and hiring external employees is used more by the larger establishments. Besides Saturday work, Sunday work and short time work are more often used by smaller establishments, whereas hiring external employees is more often used by the larger establishments.

Expected changes in shifts are only used by a minority of the establishments (3.7\%), mainly the larger establishments. Shifts seem the least flexible working time arrangement. In the producing sector changes in the shift system are used more often than in the service sector. In the service sector flexible working times and staggered working times are more frequently used to cope with fluctuations. The use of overtime, flexible working time, hiring and firing and external employees to cope with fluctuation increases with establishment size, whereas the use of short time work, Saturday work and Sunday work decreases with establishment size. For staggered working times the picture is mixed.

\subsection{Conclusions}

In the Netherlands in 2003 the average weekly operating time of establishments was 52.9 hours and the average weekly working time of employees was 28.6 hours. The decoupling rate of 1.85 is mainly realised by operating more days. The mean number of operating days is 5.6. Working on Saturdays is used to extend operating time, notably in the service sector. Also part time employment is widely used as an instrument to decouple. Like daily operating times, weekly operating hours are longer in the service sector relative to the producing sector, and in both sectors weekly operating hours increase with establishment size. Decoupling is stronger and more frequent in the service sector and in larger establishments. Working time is shorter in the service sector relative to the producing sector. Part time contracts account for this variation. However, the part time rate does not correlate with operating hours, indicating that part time work is supply-side dominated, at least in the Netherlands. Also the strong positive association with the proportion of female employees points in this direction.

From our review of working time arrangements, it may be concluded that the frequency with which the various working time patterns are used differs considerably across sectors and size classes. In the Netherlands the use of part time employment is the most widely spread working time option, followed by Saturday working. This holds both for the service sector and the producing sector. However, for the bigger establishments in both sectors, working overtime takes over the second place of Saturday working. Weighted by the 
number of employees, part time work now becomes the most important working time form, followed by staggered working time. With the exception of Saturday work and on-call work, all working time options are used more often by the larger establishments. Although establishments use staggered working time far more often than shift work, the proportions of employees involved do not differ that much. This is related to the high proportion of shift work among very big establishments in the producing sector. Overtime is most frequently used to cope with fluctuations.

The majority of firms and organisations in the Netherlands have a "standard" of 8-10 daily operating hours. A large minority (19\%) has non-standard daily operating hours of more than 10 hours. Only a small minority of $2 \%$ of the establishments operates for 24 hours per day. Also, from the fact that for most of the non-standard forms of working time the proportion of the work force involved is below $15 \%$, it may be concluded that the " 24 hour economy" is not a reality for most employers and most employees. It seems that most Dutch employees still work full-time or part-time within the normal 9 to 5 working time standard. Decentralisation, differentiation and individualisation have their impact on the way working time is regulated. Despite the various changes in the environment, including legal changes, no big changes took place between 1998 and 2003. In the Netherlands most Dutch people still have dinner between 6 and 7 p.m.

The percentage of labour costs in total costs is higher in larger establishments and in services. Similar to the proportion of females, the proportion of skilled employees in the service sector is more than twice as high as in the producing sector; the proportion decreases with establishment size. Weekly operating hours are negatively associated with the proportion of labour costs and the proportion of skilled employees, confirming that operating hours increase with physical capital intensity and decrease with human capital intensity. The correlation with labour costs is stronger in the producing sector, while the association with the proportion of skilled employees is stronger in the service sector. The association of weekly operating hours with the female rate shows a mixed picture. Our data indicate positive correlations between weekly operating time and shifts, staggered working time, Sunday, Saturday and overtime working. These working options are used to extend operating time. However, longer operating time is accompanied by lower contractual working time. This may in part explain why (changes) in the weekly operating hours and (changes in) the number of employees (employment) are positively associated. However this relationship is weak and varies between branches and between size classes. 


\section{References}

Anxo, D., G. Bosch, D. Bosworth, G. Cette, T. Sterner and D. Taddei (1995) Work patterns and capital utilisation - an international comparative study, Dordrecht: Kluwer Academic Publishers.

Bekker, S., D. Fouarge, M. Kerkhofs, A. Román, M. de Voogd-Hamelink, T. Wilthagen and C. de Wolff(2003) Trendrapport Vraag naar Arbeid 2002, OSA-publicatie A200, Tilburg: Organisatie voor Strategisch Arbeidsmarktonderzoek.

Buddelmeyer, H., G. Mourre and M. Ward (2004) The determinants of part-time work in the EU countries: empirical investigations with macro-panel data, European Economy Economic Papers 213, Brussels: European Commission.

Burns, R. N. and M. W. Carter (1985) Work force size and single shift schedules with variable demands, Management Science, 31, May: 599-607.

Delsen, L. (1995) Atypical Employment: An International Perspective. Causes, Consequences and Policy, Groningen: Wolters Noordhoff.

Delsen, L. (2002) Exit Polder Model? Socioeconomic Changes in the Netherlands, Westport: Praeger Publishers.

Delsen, L. (2005) De anorexiastrategie van NedCar, Gids voor Personeelsmanagement, 84, July/August: 26-29.

Delsen, L. and J. Smits (2002) Operating hours and working time in the Netherlands, in: F. Bauer, H. Groß and G. Sieglen (eds.) Operating Hours in Europe, Berichte des ISO 66. Cologne: Institut zur Erforschung sozialer Chancen, 79-95.

Ginneken, van, C.C.P.M. (1988) De ontwikkeling van de vraag naar deeltijdarbeid, OSA-werkdocument W 47, Den Haag: Organisatie voor Strategisch Arbeidsmarktonderzoek.

Gradus, R. (1996) The economic effects of extended shop opening hours, Journal of Economics, 64 (3): 247-263.

Lange, de, W. (1989) Configuraties van Arbeid, Zutphen: Thieme.

OECD (2004) Employment Outlook, Paris: Organisation for Economic Co-operation and Development.

Schettkat, R. and J. Reijnders (1998) The Disease that became a Model. The Economics behind the Employment Trend in the Netherlands. Washington D.C.: Economic Policy Institute.

Tijdens, K. (1998) Zeggenschap over arbeidstijden. De samenhang tussen bedrijfstijden, arbeidstijden en flexibilisering van de personeelsbezetting, Amsterdam: Welboom/Nationaal Vakbondsmuseum. 